\title{
Budget and life cycle in family business in succession process ${ }^{*}, * *$
}

\author{
Cristina Hillen ${ }^{1}$ \\ (D) https://orcid.org/0000-0002-8028-8969 \\ Email: cristina.hillen@unespar.edu.br
}

\author{
Carlos Eduardo Facin Lavarda ${ }^{2}$ \\ (D) https://orcid.org/0000-0003-1498-7881 \\ Email: eduardo.lavarda@ufsc.br
}

1 Universidade Estadual do Paraná, Departamento de Ciências Contábeis, Campo Mourão, PR, Brazil
2 Universidade Federal de Santa Catarina, Departamento de Ciências Contábeis, Florianópolis, SC, Brazil

Received on 02.15.2019 - Desk acceptance on 02.25.2019 - $3^{\text {rd }}$ version approved on 08.26.2019 - Ahead of print on 12.09.2019

Associate Editor: Cláudio de Araújo Wanderley

\begin{abstract}
The aim of this work is to analyze how the budget need is conceived in family businesses in the process of succession. There is a gap about the reasons for using the budget in the context of a family business succession process, whose characteristics and purposes of the budget reflect their need depending on the antecedents the reasons for use. The relevance of the theme lies in understanding the intergenerational succession as a part of the life cycle in family companies and the interface with the management control system (MCS) from the need of the budget with a planning and control tool. As an impact on the area, this study broadens the field of research on budget considering its characteristics and purposes in a context of organizational transition that involves succession in a family business. We adopted the single case study with data collected through semi-structured interviews, observations, and documents. Data were analyzed from the discursive textual analysis whose focus is the contents related to succession from the organizational life cycle, changes in the MCS, and budget need. The results showed that changes resulting from the succession process on the strategies of its planning (professionalization of management, creation of the holding company, and governance) interact and influence the need of the budget. This stems from the reasons for operational planning and strategic training from its antecedents associated with the organizational characteristics of the success and renewal phase of the life cycle. The contribution of the study is based on the combination of succession in family business and budget by making it possible to reflect on the need for a specific tool (the budget) to support goal setting and decision-making in this context. It will contribute to the MCS and family business by understanding the need for budgeting in the succession process. In addition, it will validate the three-phase model of the succession process in a family business as part of the organizational life cycle.
\end{abstract}

Keywords: budget, succession, life cycle, family business.

* Paper presented at the Annual Conference of the European Academy of Management, Lisboa, Portugal, June 2019.

** The authors are grateful to the National Council for Scientific and Technological Development (CNPq) and to the Universidade Estadual do Paraná (UNESPAR), for its financial support to carry out this research. 


\section{INTRODUCTION}

In the context of family businesses, succession is fundamental to continuity from one generation to the next (Handler, 1994), while the process comprises actions, events, and organizational mechanisms by which leadership in the business - and often its ownership - is transferred to the successor generation (Le Breton-Miller, Miller, \& Steier, 2004).

Succession is part of the organizational life cycle (Gersick, Davis, Hampton, \& Lansberg, 1997) which may occur during (and interfere with) its various phases (Gersick et al., 1997; Giovannoni, Maraghini, \& Riccaboni, 2011). In them, organizational activities and structures differ (Quinn \& Cameron, 1983), involving the process of development and decision-making (Handler, 1994).

Succession, thus, is characterized as a relevant moment in the life of the family business and implies changes in management due to the impact on the activities resulting from command change (Roth, Tissot, \& Gonçalves, 2017). In this sense, it can be an opportunity to improve the management of the company as it is a time of renewal and strengthening for organizations (Roth et al., 2017) based on the challenges imposed that require strategies to act differently (Oro \& Lavarda, 2019).

The literature on succession presents multifaceted models to understand it as a process (Cabrera-Suárez, De Saá-Pérez, \& García-Almeida, 2001; Chrisman, Chua, Sharma, \& Yoder, 2009; Le Breton-Miller et al., 2004; Nordqvist, Wennberg, \& Hellerstedt, 2013). Although the specificities of each model vary, they are aligned with the three-phase model of Le Breton-Miller et al. (2004), which considers the stages of planning, training and development of successor, and transfer of power and ownership (Daspit, Holt, Chrisman, \& Long, 2015; Le Breton-Miller et al., 2004).

Succession, considered as part of an evolutionary process (Le Breton-Miller et al., 2004), occurs over many years and is related to the patterns that define the life cycle of the company which, in turn, affect the system (Giovannoni et al., 2011), as well as their artifacts such as planning and budgeting (Frezatti, Relvas, Nascimento, Junqueira, \& Bido, 2010).

In this sense, organizations use budgeting for different reasons, such as operational planning, performance evaluation, communication of objectives, and strategy formation (Hansen \& Van Der Stede, 2004). These reasons arise in different circumstances (Hansen \& Van Der Stede, 2004), linked to the organizational life cycle
(Lester, Parnell, \& Carraher, 2003; Miller \& Friesen, 1983, 1984), whose succession is part.

In Brazil, studies have already signaled research efforts regarding succession in family businesses (Flores \& Grisci, 2012; Oliveira \& Silva, 2012; Oliveira, Albuquerque, \& Pereira, 2012; Roth et al., 2017; Silva \& Muniz, 2006; Waiandt \& Danvel, 2008). Also, studies were carried out from the perspective of the organizational life cycle of Lester et al. (2003) by addressing, for example, elements of family influence in the Family Influence on Power, Experience, and Culture (F-PEC) model (Frezatti, Bido, Mucci, \& Beck, 2017). In addition, the Brazilian literature also includes studies on the life cycle in family companies based on other perspectives, evidencing life cycle, succession, and governance (Cançado, Lima, Muylder, \& Castanheira, 2013; Oliveira et al., 2012), life cycle and budget (Marques, Cunha, Faveri, \& Walter, 2014), and life cycle and management accounting artifacts (Assunção, Luca, Vasconcelos, \& Cardoso, 2014) that were performed in non-specific contexts of family companies.

Nevertheless, there is a gap in the literature regarding the harmonization of family business succession in the life cycle approach and the budget in this context. Thus, we seek to fill this gap, relying on Le Breton-Miller et al. (2004), as to the process of succession, on Lester et al. (2003), to identify the timing of the succession process in the life cycle stages, and on Hansen and Van der Stede (2004), to identify the need for the budget at this moment.

Based on this, this research seeks to understand how the budget needs to be conceived in a family business in the process of succession as a moment in the organizational life cycle. This knowledge is relevant to understand how the budget need from its use reasons is associated with the moment of succession within the organizational life cycle. In addition, it allows the understanding of the perception of the family executives regarding the process of business management from the succession.

A more in-depth look at family-owned companies is interesting in order to discuss the particularities of these organizations in terms of the budget need for the intergenerational succession process. The absence of such a discussion represents a limitation in the scope of budget studies in family businesses and ignores the need for the budget at a specific time related to intergenerational succession as a form of managerial control aimed at decision-making and its continuity between generations. 
Changes in the managerial control system in the context of business succession still constitute a field under-researched in the literature on the subject (Giovannoni et al., 2011; Salvato \& Moores, 2010).
Few studies attempt to combine the dimensions of the succession process with the role of the managerial control system beyond the technical and functional aspects (Bracci \& Maran, 2012).

\section{LITERATURE REVIEW}

\subsection{Succession and Life Cycle in Family Businesses}

A family business is the one based on the view of the controlling family aimed at sustaining the business through the generations (Chua, Chrisman, \& Sharma, 1999). Sustaining business across generations refers to the intergenerational succession that includes transferring leadership and ownership from a senior generation to a junior generation (Sharma, Chrisman, \& Chua, 2003). Intergenerational succession, in turn, is understood as a multi-stage process that ideally requires increasing involvement of the successor in the business, at the same time as the predecessor reduces its involvement until there is a real transfer of leadership in the organization (Handler, 1994; Le Breton-Miller et al., 2004; Nordqvist et al., 2013).

The succession process is considered one of the most critical challenges faced by family-run companies, being the most important concern of their leaders (Le Breton-Miller et al., 2004; Sharma et al., 2003). It represents the crucial moment of the organizational life cycle independently of the stage of development of the company (Cesaroni \& Sentuti, 2019; Gersick et al., 1997). At that moment, the company's directions are directed or conditioned by the goals, preferences, ambitions, and personal choices of those involved (predecessor and successor), family members' relationships, and the behavior they put into practice (Cesaroni \& Sentuti, 2019).

Le Breton-Miller et al. (2004) understand succession as a process with the elements actors, contexts, and process with different phases (Daspit et al., 2015; Le Breton-Miller et al., 2004). According to the three-phase model of Le Breton-Miller et al. (2004), the succession process can be understood from the stages of (i) planning, (ii) training and development of successors, and (iii) transfer of power and ownership (Daspit et al., 2015; Le Breton-Miller et al., 2004).

The planning stage refers to the establishment of basic rules related to a vision for the future of the business, with creation and monitoring of the succession plan and the identification of succession candidates, as well as establishing rules for the selection of candidates and guidelines for its formation (Le Breton-Miller et al., 2004). The successor training and development stage is based on formal education, on-the-job training, career development, and outside-company experience. It also involves monitoring the performance of the candidate, as well as the need to redirect the training according to the plan (Le Breton-Miller et al., 2004). Finally, the stage of transfer of power and ownership is given by the process of transmission and not interference, which includes the transfer of power itself and ownership, if applicable. That is, the holder leaves and the chosen successor assumes his role (Le Breton-Miller et al., 2004).

It should be noted that leadership can be transferred to both a family member and a non-family member. With the transfer of leadership to a non-family member, i.e., a transfer of management, the company remains a family business, as there is no transfer of ownership. In this sense, when planning, some strategies, such as managerial professionalization, family governance, and the creation of holdings, can lead to better results (Roth et al., 2017).

The professionalization includes the insertion of non-family professional managers with experience and training for the specific area to be improved in order to better conduct business (Oliveira et al., 2012; Oro \& Lavarda, 2019). In addition, it contemplates qualification of directors from adequate training to their positions (Giovannoni et al., 2011).

In this understanding, both the process of succession and the process of professionalization of family companies may rely on governance mechanisms for offering alternatives for the company to deal with the problems that emerge at these moments (Oliveira et al., 2012). The governance of the family business applies more generally, whether a public company or not, to refer to the practices adopted in order to reduce the conflicts of interest between family and company. Thus, the relations between family and company are delimited by means of bodies, councils, agreements, and rules that formally explain the boundaries of these relations (Oliveira et al., 2012).

Still in the context of succession planning, Lodi (1998) advocates the creation of a societal structure, such as holding companies, which, once implemented, tends to minimize conflicts, not affecting the business, 
characterizing a process of equity division and succession reorganization. For Mamede and Mamede (2011), the creation of a family holding company is an essential strategy for ordering the assets of a family or even to optimize the corporate structuring of a company or group of companies.

In view of the above, it is important to understand succession in the light of the company's life cycle over time, interpreting its history, evaluating the decisions made, and identifying the company in each of the dimensions of development, from its strategic challenges. The prior identification of the company in each of the development cycles can provide insights to better understand the succession process relationships (Cançado et al., 2013).
Miller and Friesen $(1983,1984)$, based on what the literature points out from the various stages of organizational development, generated an approximate conceptual typology of the stages of organizational life based on the phases: (i) birth; (ii) growth; (iii) maturity; (iv) revival; and (v) decline. In the same context, Lester et al. (2003) proposed an organizational life cycle model that supports the work of Miller and Friesen $(1983,1984)$ and is applicable to all organizations based on five stages: (i) existence; (ii) survival; (iii) success; (iv) renewal; and (v) decline. Such typologies are used to describe differences in strategy, structure, decision-making style, and situational or context factors from organizational characteristics considered essential at each stage of the life cycle, as listed in Table 1.

Table 1

Organizational characteristics of life cycle stages

\begin{tabular}{|c|c|c|c|c|}
\hline Life cycle stage & Situation & Structure & Decision-making style & Strategy \\
\hline Existence & $\begin{array}{c}\text { Small } \\
\text { Young } \\
\text { Homogeneous }\end{array}$ & $\begin{array}{c}\text { Informal } \\
\text { Simple } \\
\text { Owner-dominated }\end{array}$ & $\begin{array}{l}\text { Centralized } \\
\text { Trial and error }\end{array}$ & Prospector/first move \\
\hline Survival & $\begin{array}{l}\text { Medium-sized } \\
\text { More competitive } \\
\text { environment }\end{array}$ & $\begin{array}{l}\text { Functional } \\
\text { Some formality }\end{array}$ & $\begin{array}{l}\text { Some delegation } \\
\text { Begin formal information } \\
\text { processing }\end{array}$ & $\begin{array}{l}\text { Analyzer/second mover/ } \\
\text { differentiation }\end{array}$ \\
\hline Success & $\begin{array}{l}\text { Heterogeneous } \\
\text { environment } \\
\text { Larger size }\end{array}$ & $\begin{array}{l}\text { Formal } \\
\text { Bureaucratic } \\
\text { Functional }\end{array}$ & $\begin{array}{l}\text { Reliance on internal } \\
\text { information processing }\end{array}$ & Defender/segment control \\
\hline Renewal & $\begin{array}{c}\text { Very heterogeneous } \\
\text { environment } \\
\text { Very large }\end{array}$ & $\begin{array}{l}\text { Divisional } \\
\text { Some matrix }\end{array}$ & $\begin{array}{l}\text { Sophisticated controls } \\
\text { Formal analysis in } \\
\text { decision-making }\end{array}$ & $\begin{array}{c}\text { Analyzer/combination } \\
\text { differentiation } \\
\text { Low cost }\end{array}$ \\
\hline Decline & $\begin{array}{l}\text { Homogeneous } \\
\text { and competitive } \\
\text { environment }\end{array}$ & $\begin{array}{c}\text { Formal } \\
\text { Bureaucratic } \\
\text { Mostly functional }\end{array}$ & $\begin{array}{c}\text { Moderate } \\
\text { Centralization } \\
\text { Less sophisticated } \\
\text { information processing }\end{array}$ & $\begin{array}{c}\text { Reactor/product/service } \\
\text { Breadth } \\
\text { Low cost }\end{array}$ \\
\hline
\end{tabular}

Source: Modified from Lester et al. (2003).

This model was validated by some studies (Frezatti et al., 2010; Lester et al., 2003; Lester, Parnell, \& Menefee, 2009) and, specifically, in family companies in the Brazilian context (Frezatti et al., 2017). It is worth mentioning that this model does not recognize intermediate stages that companies pass through, thus characterizing a limitation (Frezatti et al., 2010, 2017).

The organizational life cycle involves stages with various activities and organizational structures combined with different forms of organizational control (Moores \& Mula, 2000), such as the management control system (MCS) and budget, discussed below in relation to family businesses.

\subsection{MCS and Budget in Family Businesses}

The company's philosophy, structural, procedural, and relational components are determinants in the way the company is managed (Child, 1997). Thus, it is based on the MCS concept that includes both formal and informal mechanisms, processes, systems, and networks used by organizations (Ferreira \& Otley, 2009; Malmi \& Brown, 2008). As members of the MCS, the budget element stands out, which includes planning, execution, and control as a management process (Anthony \& Govindarajan, 2008). In this process, the organization's strategies have an effect on the decisions made (Vancil, 1973), and the 
budget becomes important to implement these strategies (Oro \& Lavarda, 2019) and effectively such decisions (Vancil, 1973).

Through budgets, the activities of different parts of the organization can be coordinated and controlled by incorporating measures and techniques that are in line with the responsibilities delegated to managers under the organization structure (Bruns \& Waterhouse, 1975). The budget varies among companies because of some are more formal than others or more elaborate and time-consuming. Others require top management involvement, while others do not (Merchant \& Van Der Stede, 2007). However, budget-related behavior depends on various aspects of the organizational structure, such as centralization, autonomy, and the degree to which activities are structured (Bruns \& Waterhouse, 1975).

The budget is used as an instrument for a variety of purposes, but the studies use different labels and categories (Hansen \& Van Der Stede, 2004). Hansen and Van der Stede (2004) generated a list of the main purposes for which most organizations use budget. This list covers the purpose of both short-term planning (operational planning) and long-term planning (strategy formulation), the role of communicating these plans (goal communication), and performance evaluation. From these purposes, Hansen and Van der Stede (2004) demonstrated the organizational structure, the organizational strategy, the operational environment, and the external environment, as their antecedents when reflecting on the importance of each purpose.

In recent years, investigations on MCS and family businesses have drawn the attention of several authors because of the nature of these companies gives the MCS a series of specificities that its understanding requires specific studies (Cesaroni \& Setuti, 2019). However, there are few studies that analyze how MCS can combine and interact with succession, a typical process of family business change (Bracci \& Maran, 2012; Cesaroni \& Setuti, 2019; Giovannoni et al., 2011; Leotta, Rizza, \& Ruggeri (2017); Salvato \& Moores, 2010), allowing the development of knowledge on the subject.

Specifically in the context of family-owned enterprises, Giovannoni et al. (2011) emphasize that managerial accounting supports the transfer of knowledge between generations and between family and non-family owner managers. In addition, they present evidence that increased complexity, through succession, professionalization, and growth, creates a need for change to a more formal control system, even if the family relies on non-family management.
Still, Bracci and Maran (2012) showed that the MCS played a role of substitution and mediation in the process of succession in family businesses. It replaced previous practices and represented a source of trust and legitimacy for successors. It mediated the predecessor's intentions to maintain previous practices and family ties and the willingness of successors to bring about radical change. According to Leotta et al. (2017), MCS helps people share a set of values to guide them in formulating company strategy. Thus, the MCS provides organizational actors with a language that, representing the managerial view of the successor, can integrate it into the shared view within the family organization, as well as contribute to the construction of the leadership profile of the junior generation.

More recently, Cesaroni and Sentuti (2019), in exploring the relationship between change in MCS and succession process in family businesses, have shown the interactions between the two processes and influence of one another. They pointed out that human and nonhuman performances may represent heterogeneous actors developing MCS giving special attention to the successor, including their goals and motivations, in order to better understand their role in the MCS process.

Petry and Nascimento (2009) sought to identify the most frequent characteristics in the management model of family companies in order to explain their longevity, from the perspective of the succession process. They observed that, in the larger and longer-lived companies, the management process (strategic planning, operational planning, planning execution, and planning control) is formal, measuring strategies, and establishing standards for performance and resource utilization, enabling the comparison between the expected results and the strategies adopted and effectively achieved. This did not occur in a significant part of smaller and less long-lived companies, since the management process is fragile, incomplete, and in some cases non-existent.

As observed in some studies described, they analyzed the influence of the MCS on family companies considering the succession. In this sense, it is assumed that the need for budget tends to be accentuated when the succession depends on the interaction and influence that these processes exert between each other, according to the stage of life in which it happens and the organizational characteristics which characterize the antecedents to the reasons for using the budget.

In view of the above, the theoretical model of the research was set up, which reflects the synthesis of the themes analyzed as illustrated in Figure 1. 


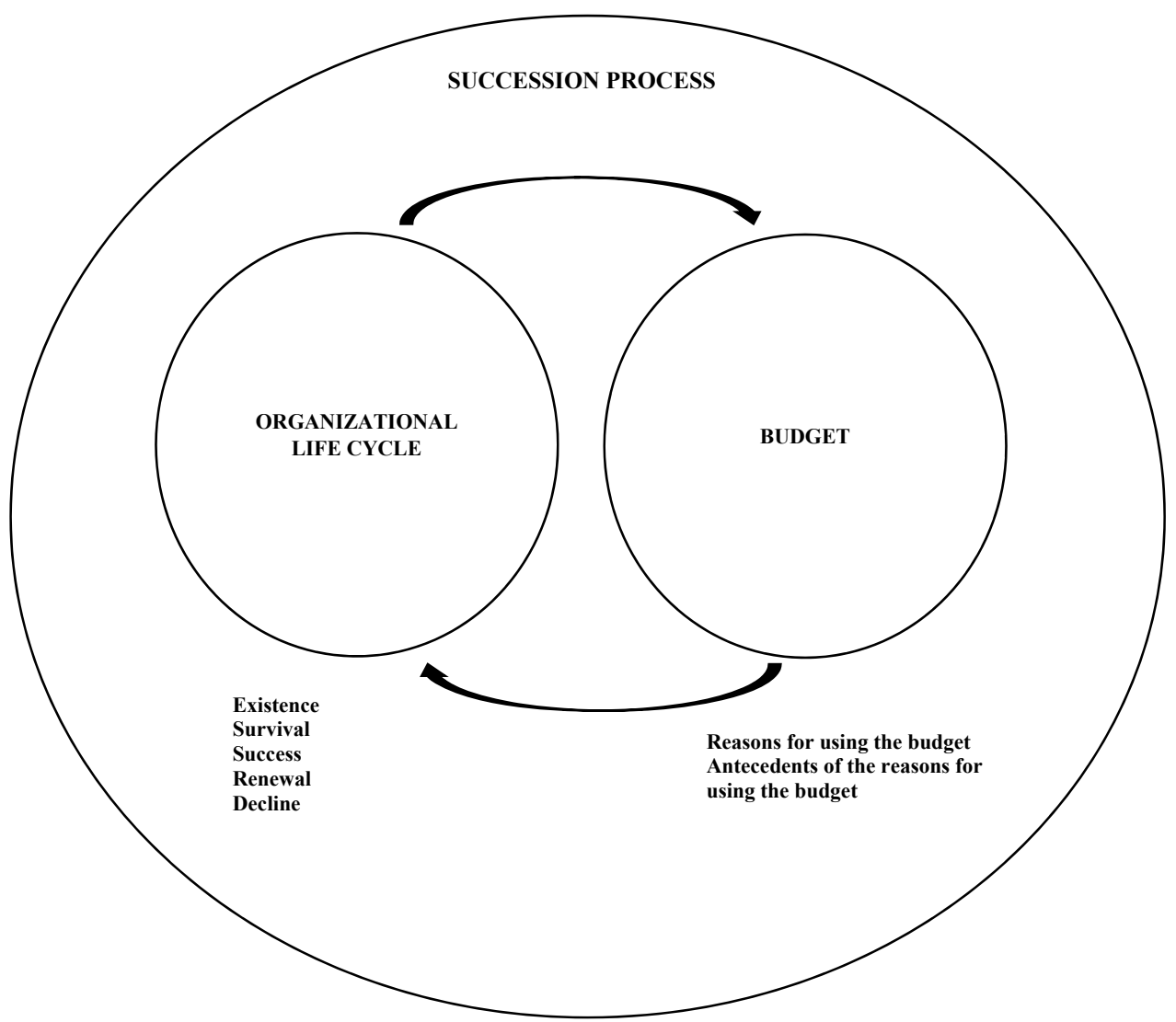

Figure 1 Theoretical research model

Source: Elaborated by the authors.

The theoretical research model seeks to systematize the need for the budget in a family business by observing the interaction with the organizational life cycle, with emphasis on the stages in which the succession process takes place and its impact in terms of budget need arising from the professionalization of management with reflection in succession.

\section{RESEARCH METHOD}

In order to respond to the proposed objective, a qualitative research was developed, based on a single case study, descriptive and cross-sectional (Sampieri, Collato, \& Lucio, 2013). The single case study allowed the investigation to go deeper into the phenomenon investigated within its real context and this strategy is relevant for research in family companies with characteristics similar to those of the present investigation (De Massis \& Kotlar, 2014).

The company selected for this study, called as Retail Group for the purposes of this study, has unique characteristics that make it a logical candidate (De Massis \& Kotlar, 2014). It is characterized as a Brazilian family business group, from the supermarket retail segment and headquartered in the state of Paraná. Preliminary surveys revealed its economic relevance in the region in which it is located, and the representativeness in relation to its position in the supermarket retail sector of the state (Associação Paranaense de Supermercados, 2017; Nunes, 2018).

It was verified that, in the company, there is intense family involvement in the management, and that it is in the process of intergenerational succession, in which the budget need is expressed openly by the family leaders. A significant aspect of this is that, with more than five decades of the company's existence, one of the founders remains active in management, allowing more detailed access to the foundation and trajectory of the business.

The contact with Retail Group was first made with a survey on the company's electronic website, in its digital media, and later with a direct contact with the organization by telephone in April 2018, as well as contacts by WhatsApp with the accountant, in May 2018. A preliminary interview was conducted with the accountant in May 2018 to provide 
evidence that the company would meet the requirements of the study.

This preliminary investigation aimed to identify the following characteristics: (i) family business; (ii) intergenerational succession process; (iii) family involvement in management; (iv) occurrence of organizational changes; (v) structure of the managerial control system (MCS); and (vi) use of budget planning and control. On that occasion, it was verified that the group had the necessary characteristics for the development of the research, and it was identified that the group experienced organizational changes, improving its MCS, and implementing the budget planning and control.
In order to conduct the interviews with those responsible for management, on July 18 , in a meeting with the accountant, the Protocol of the Study and the Free and Informed Consent Form (FICF) of the research were presented and submitted for subsequent approval of the board members and board of directors, which took place in a meeting held on July 23, 2018. After approval, the interviews with the directors and members of the board of directors were scheduled for the beginning of August.

Data collection was based on the constructs in Table 2, listed in categories and subcategories, as well as the base authors used for their structuring.

Table 2

Research constructs

\begin{tabular}{|c|c|c|}
\hline Categories & Subcategories & Authors \\
\hline Life cycle & $\begin{array}{l}\text { Birth or existence } \\
\text { Growth or survival } \\
\text { Maturity or success } \\
\text { Revival or renewal } \\
\text { Decline }\end{array}$ & $\begin{array}{l}\text { Miller and Friesen }(1983,1984), \\
\text { Lester et al. }(2003)\end{array}$ \\
\hline MCS and budget & $\begin{array}{l}\text { Reasons for using the budget (operational } \\
\text { planning, strategy formation, communication } \\
\text { of goals, and performance evaluation) } \\
\text { Antecedents of the reasons for using } \\
\text { the budget (organizational structure, } \\
\text { organizational strategy, operational } \\
\text { environment, and external environment) }\end{array}$ & $\begin{array}{l}\text { Bruns and Waterhouse (1975), } \\
\text { Hansen and Van Der Stede (2004), } \\
\text { Le Breton-Miller et al. (2004), } \\
\text { Merchant and Van Der Stede (2007), } \\
\text { Malmi and Brown (2008), } \\
\text { Ferreira and Otley (2009) }\end{array}$ \\
\hline Succession process & $\begin{array}{c}\text { Planning } \\
\text { Training and development of successors } \\
\text { Transfer of power and ownership }\end{array}$ & \\
\hline
\end{tabular}

MCS = management control system.

Source: Elaborated by the authors.

Data were collected between April and August 2018 in individual semi-structured interviews, observations, and documents provided by the company. Seven interviews were carried out with an average duration of 45 minutes each. All the interviews were recorded in audio and later transcribed. The transcripts were sent to the interviewees for verification and/or rectification and/or complementation of content, and only after the return, they began to compose the corpus for the analysis process (Bauer \& Gaskell, 2017).

The interviewees were selected based on the following criteria: (i) be a member of the owning family and participating in the management; and (ii) be involved with the management process. The interviews were conducted at the company's premises during office hours. Before the beginning of each interview, the Study Protocol and the FICF were presented, as well as the authorization to record the interview. The signatures of the interviewees were collected, and a copy of the documents was given to them. All the interviewees agreed and authorized the recording. The list of selected interviewees is presented in Table 3. 
Table 3

Interviewees for the study

\begin{tabular}{|c|c|c|c|c|c|}
\hline Interviewee & $\begin{array}{l}\text { Function according } \\
\text { to organization chart }\end{array}$ & $\begin{array}{l}\text { Business time } \\
\text { (years) }\end{array}$ & Age (years) & Formation & $\begin{array}{l}\text { Interview duration } \\
\text { time (min) }\end{array}$ \\
\hline E1 & $\begin{array}{c}\text { Information } \\
\text { technology (IT) } \\
\text { officer - Employee }\end{array}$ & 10 & 30 & $\begin{array}{l}\text { Internet technology } \\
\text { and systems }\end{array}$ & 45 \\
\hline E2 & $\begin{array}{l}\text { Human resources } \\
\text { manager - Employee }\end{array}$ & 3 & 44 & Economics & 52 \\
\hline E3 & $\begin{array}{c}\text { Financial manager - } \\
\text { Employee }\end{array}$ & 29 & 47 & $\begin{array}{c}\text { Financial } \\
\text { management }\end{array}$ & 47 \\
\hline E4 & $\begin{array}{l}\text { Accountant - } \\
\text { Employee }\end{array}$ & 20 & 36 & Accounting & 67 \\
\hline E5 & $\begin{array}{l}\text { Commercial director } \\
\text { - Firstborn heir }\end{array}$ & 36 & 47 & Agronomist engineer & 70 \\
\hline E6 & $\begin{array}{l}\text { Marketing director - } \\
\text { Youngest heir }\end{array}$ & 16 & 36 & $\begin{array}{l}\text { Advertising and } \\
\text { publicity }\end{array}$ & 18 \\
\hline E7 & $\begin{array}{l}\text { Managing director } \\
\text { - Predecessor - } \\
\text { Matriarch }\end{array}$ & 54 & 66 & $\begin{array}{l}\text { Equivalent to high } \\
\text { school }\end{array}$ & 19 \\
\hline
\end{tabular}

Source: Elaborated by the authors.

The documentation served mainly for triangulation and as a supplementary source to aid in understanding the main events (Bauer \& Gaskell, 2017). The visits for observations and obtaining documents occurred in the headquarters, two branches besides the distribution center (which also houses the administrative headquarters). In such opportunities, observations were made, as well as informal conversations recorded in the research diary (Stake, 2011).

Data generated by the semi-structured interviews after transcription, the observation protocols, and the documents were understood as texts (Bauer \& Gaskell, 2017). These texts were codified by relating their passages to the developed categories and subcategories (Bauer \& Gaskell, 2017) presented in Table 1. The discursive textual analysis was sequentially performed (Moraes, 2003), aiming to interpret the meanings attributed by the respondents to the need for budgeting by pointing to intergenerational succession in the organizational life cycle.

\section{DISCUSSION AND RESULTS OF THE RESEARCH}

\subsection{Contextualization of the Retail Group}

Retail Group was founded in 1964 by the patriarch and the matriarch of the family. It has been operating for more than five decades in the state of Paraná (Brazil) in the supermarket retail segment (Figure 2). It is composed of seven stores, a distribution center, and a carrier, employs 964 employees and, according to its billing, is a large company based on the criteria of Internal Revenue Service. It has three heirs and is currently managed by the matriarch and two heirs who, together with a third heir who does not participate in the management, hold the entire capital of the company. The decisions of the company have direct involvement of the family members who influence the adopted strategies. 


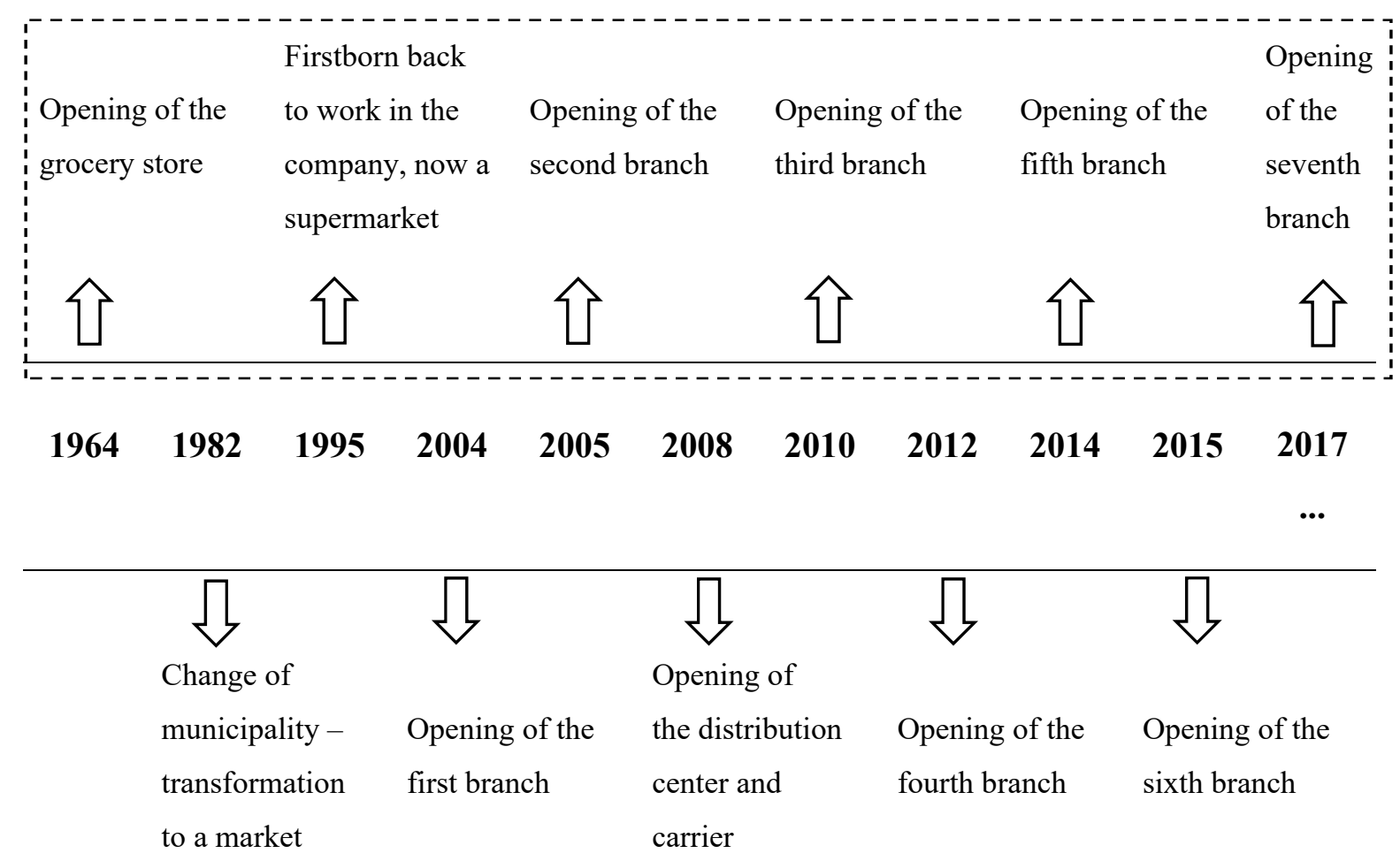

Figure 2 Timeline of the evolutionary history of Retail Group Source: Elaborated by the authors.

Figure 2 represents the evolutionary history of Retail Group over time. It should be noted that the significant expansion of Retail Group occurred in 2004, 40 years after its birth, with the opening of its first branch, and increased from 2010. After the opening of the second branch, Retail Group focused on opening the distribution center and the carrier in order to meet the demands of the headquarter and branches, as well as the opening of new branches that occurred every two years as of 2010 .

\subsection{Analysis and Discussion of Intergenerational Succession from the Organizational Life Cycle}

Lester et al. (2003), based on Miller and Friesen (1983, 1984), propose an organizational life cycle classification that applies to companies of different sizes and distinguishes between existence, survival, success, renewal, and decline based on the organizational characteristics related to situation, structure, style of decision-making, and strategy. Thus, we sought to analyze the organizational life cycle of Retail Group based on the stages and organizational characteristics of Lester et al. (2003), according to Table 1 , to identify in which of them the succession occurred from their organizational characteristics and the budget requirement at that time.
The Retail Group birth/existence phase (Lester et al., 2003; Miller \& Friesen, 1983, 1984) occurred in 1964, when the couple opened a grocery store, whose strategy was to seek to become a viable business with a simple and informal structure, managed by its owners, characterizing the leadership and centralized decision-making style.

The growth/success phase (Lester et al., 2003; Miller \& Friesen, 1983, 1984) was the period from the birth to 1981 of Retail Group, since it was the period in which the company established its competencies. Sales growth and accumulation of resources were sought. These aspects characterized its strategy, but without established functional structure, with the still informal procedures, the business relied only on the founders' role in leadership and decision-making.

In 1982, the location of the business changed to a more populous city. Such a change was due to the founders' desire to provide better education for heirs. The structure and conduct of the businesses followed the same characteristics, comprising a birth/existence phase in the new locality because it was sought to conquer new customers for the business with a market characteristic, and no more a grocery store. From the conquest of new customers, it was followed to the stage of growth/success, in which the market counted on three cash operators and an administrative office. The structure had some 
hierarchy with the presence of the cash supervisor, the existence of informal controls being the leadership, and decision-making centered on the founders.

In the 1990s, with the construction of a new headquarters for the market, becoming a supermarket, and due to economic aspects, the family handed over a farm to the bank to pay out working capital loans. In this context, in 1995, the first-born, graduated in agronomy and working in a multinational, at the request of the matriarch (E7), decides to return to work in the family business.

As a result, Retail Group went through the stages of maturity/survival and revival/survival, growth/survival, to be in the growth/success stage in 2001, and in 2005, to open the first branch store of Retail Group; the firstborn was responsible for administration business. According to E4, "E5 that gave the mood to be able to move on, to open branches, to open stores". Still, according to E4, "E5, who is the eldest son, entered into society and came to take care of, it was he who began to want to change some things, get out of that familiar matter and come changing the level of the company".

From 2004 onwards, the company experienced the growth/success phase (Lester et al., 2003; Miller \& Friesen, $1983,1984)$ by 2011 , when it opened two more branches: a distribution center and a carrier. During this period, Retail Group improved its competencies and enjoyed success in the supermarket retail market. The strategy was based on the search for sales growth and the accumulation of resources in an attempt to obtain advantages on a larger scale. A function-based structure was established and procedures were more formalized, but authority had not been delegated. The process of succession started to be dealt with in 2010, with the illness of the patriarch, who died in 2011. This process was suspended due to friction between heirs.

In 2014, the fifth branch store was opened and, in 2015 , the sixth, which also marked the continuity of the growth/success stage (Lester et al., 2003; Miller \& Friesen, 1983, 1984) for the search for increased sales and accumulation of resources, the authority begins to give evidence of delegation, and procedures have been formalized. In 2017, the seventh branch was opened and in the face of this context, E5 stated:

because we have 7 stores and then we had to ... the last one, the most recent store ... we felt our processes, we got to the ... let's say we almost overturned, I say, we arrived at the maximum of what we were doing it, so we had to restructure, we were restructuring, automating our processes for the shipment of products, so that we could have more stores. So, we brought people who understood the area of logistics and it was defined that here we will support up to 10 stores. Then up to 10 stores, in the direction that we are, with this structure that we have, it works. Above 10 stores, we will have to make another structure.
During this period, Retail Group goes through a growth/survival phase with a certain slowdown to restructure and then moves on to a maturity/survival and revival/survival phase that opens the way to a new growth/ success phase in the middle of 2018 (Lester et al., 2003; Miller \& Friesen, 1983, 1984). Due to the opening of the seventh branch without adequate budget-based planning, especially in relation to logistics, the management used external auditing and hired a logistics consultancy to evaluate processes and structure.

The owners realized they were unprepared to meet the demand of all the branches, referring to the use of the term "almost overturned". Based on the diagnosis presented by the consultants, the owners of Retail Group focused on the restructuring of the logistics area by acquiring a system to monitor purchases and deliveries of goods by suppliers based on schedules, as well as for the distribution of goods to the branches as requested.

Due to the desire to open new branches, a civil engineer was also hired to plan the future works, as well as to take care of the maintenance of the existing branches (E5). This situation caused a moment of maturity on the part of the managers who, instead of opening the eighth branch, as they wanted, focused on the necessary restructuring not to cause a possible discontinuity of the business, for not being able to meet the demand of the open branch stores (E5). Faced with this restructuring, Retail Group has returned to the growth phase, evidencing the need to review strategic planning and budget implementation.

Between 2011 and 2017, Retail Group underwent significant changes, especially after 2017, in its strategies, organizational structures, functions, and management systems. These changes included the training of nonfamily managers, as well as the increasing formalization of the MCS, as well as the hiring of consultants and auditors that reinforced the need to implant and implement the budget mainly due to the resumption of the succession process in 2018 (E5). These aspects characterize the formalization as evidenced by Giovannoni et al. (2011).

\subsection{Analysis and Discussion of the MCS and Budget}

Accounting was internalized in 1995 with the return of the eldest son. Due to the growth of Retail Group from the year 2011, its family management was based on the structuring and formalization of the controls and processes, as well as the hierarchy with the re-elaboration of the organization chart. In this sense, the management committee based on four pillars (accounting/controlling, financial, human resources, and information technology) was established to support the decision-making of the 
owners (E5). An enterprise resource planning (ERP) system was deployed and consultants were hired to develop, what was termed, control, financial, human resources projects, and currently the projects of external audit and logistics. E5 emphasized: "I believe that the professionalization of these pillars that I cited was one of the growth strategies."

The organizational structure of Retail Group depends on formal and informal controls reflected in its MCS, a procedural component of the organization that controls its activities. This evidence is in line with the literature (Anthony \& Govindarajan, 2008). Decision-making in Retail Group is centered on the heirs depending on the matriarch's endorsement. Such a feature reduces the perceived control by employees at lower levels of the organization, which is also in line with the literature (Child, 1997). As the procedures and areas of authority are not clearly defined, structuring control is replaced by the interpersonal control of the owners, corroborating the findings of Bruns and Waterhouse (1975), which are insufficient and inadequate for the size of the company, and the need for the budget is presented as a means of control mainly in the speech of the members of the administrative council.

The budget is still in the implementation stage of the budget allocations of each cost center established according to literature. The difficulty in making these funds feasible relates to the managers of each branch that are being trained to do so. The ERP system is already prepared and configured in terms of cost centers and realized values, lacking the budget targets for later confrontation and elaboration of the statements that are also prepared.

As size and organizational differentiation changed during the course of Retail Group, which had the succession of the patriarch in its context, the budget became the cornerstone of its management control process, and is directly related to the use of formal management controls and standardized information flows (Bruns \& Waterhouse, 1975; Child, 1997). Considering the structural aspects of Retail Group, in addition to formally establishing the specification of individual roles and tasks to be performed, it is necessary to trust and enable employees to act within their sphere of responsibility as recommended by the literature (Ferreira \& Otley, 2009).

\subsection{Need of Budget in Relation to Intergenerational Succession}

The process of succession of the Retail Group is understood from three moments: (i) beginning of the planning of the succession when the patriarch becomes ill; (ii) death of the patriarch, transfer of ownership of the patriarch to the heirs, and suspension of the process of succession; and (iii) resumption of the succession process in 2018 , considering the succession of the matriarch and his heirs, as well as the transfer of ownership. Such moments contemplated the phases of the model of Le Breton-Miller et al. (2004).

As already evidenced, in a period prior to 2011, a dialogue on the planning of succession began, given that the patriarch was sick and died in 2011. According to E4:

we tried to do, before the patriarch passed away, we were in a complete process of holding, came the lawyers, meetings and meetings, then when he passed away, everything stopped, for a long time nobody talked about it, because the family became destabilized, you know.

The succession of the patriarch occurred naturally since in addition to being sick, the heirs grew up working in the business. The youngest heir said he has been in business since birth (E6). The eldest son E5 pointed out that

I was raised inside the company and I went out to study... So, I was 11 years old. And since then I live inside the store, I went through all sectors of the company and ... I went to Curitiba for the third year of high school and I attended the college there. So, I was off from 87 to 93.

\section{According to E4:}

\begin{abstract}
The family was adapting this way... was leaving little by little ... They were taking over the activities that had to be done. But then E5 has taken a more direct role, in this administrative matter, it is up to E5, anything we have to do is up to E5.
\end{abstract}

The matriarch and the heirs continued to act in the same way. What changed was that the young heir assumed the functions of the father, related to the produce industry, and that he had advised him for some time and the exit of one of the heirs from the functions that he performed. The eldest son continued his duties, focusing more on the management of the group as a whole. Therefore, there was no formal and planned preparation of the succession. Another observation is that after the death of the patriarch there was a transfer of capital to the heirs who joined the corporate structure together with the matriarch (E1, E2, E4).

The process of succession of the matriarch and his heirs was rescued in 2018. It had been suspended because of friction between the heirs. According to E4 "it was a long time without broaching this subject, because the family was a little disturbed, it was kind of like that, one thinking that would gain less than the other". In this sense, the budget becomes relevant as a support tool for the control, decision-making, and implementation of the strategies, being required by the owners who, after the 
misunderstandings understand the tool as a support in this process. According to E4:

today I realize that this is easier, they have reunited again, it is perhaps I think the understanding of the parties, and the family issue is stronger, I think that the union of the family can be fundamental so we could do that, because sometimes by implication something did not come out, decisions were not taken and we expected.

The succession of the matriarch and the heirs is something that worries, being a consensus the hiring and preparation of a non-family manager. E6 emphasized that if the mother dies everything dies. On her succession and succession of the heirs, the matriarch pointed out that:

I have the impression; a lot of fear, you know ... I have this fear with him, because we want him to have successors, but the grandchildren are all doing medical school, right, ...often, we inside the company think that we are doing well and are not doing well, maybe having someone... So we, I want and I'm sure I'll find someone who gives continuity, there are many so old, experienced within the company ... very good boys that formed with me, who know how I like... I know they have a very great value and I'm sure they will fight to continue in the company and to grow ... and they fight, the business also has to grow, when my husband was missing, I made everybody work, let's move on, life goes on, right. So, my succession, I think ... it's not easy, but I'm confident. (E7)

On the succession of the matriarch and the subsequent succession, the eldest son (E5) emphasized:

\begin{abstract}
In the part of succession ... we have ... we are elaborating the holding company, the family holding companies, but my idea, let's put it this way, I am a successor of my parents, but I believe I will not have successor. My kids will not want to go into business. So, the idea is to do corporate governance, a deployment of that. So, we, since I joined the company, we've been taking a lot of steps, right? So, the biggest difficulty today is finding the right people in the right places.
\end{abstract}

In relation to the succession of the patriarch, there was no planning as recommended by the studies of Le Breton-Miller et al. (2004) and other authors. From the aspects dealt with by the heirs as to whether the leadership succession was of the matriarch or of them, it was evident the necessity and the will to professionalize the management, if they decide to cede control to professional managers (Giovannoni et al., 2011).

This aspect points to the need to plan a succession process for the matriarch and his heirs (E5, E6, E7), encompassing strategies that meet the desires evidenced (professionalization of management, creation of the family holding company, and implementation of family governance). The budget to implement these strategies was recurrent in both the contracted consultants guidelines (E4), as well as in owners' and administrative council speech to support the succession process.

Specifically, on succession planning strategies and budget E4 exemplified:

\begin{abstract}
We are in the middle of the process of creating holdings and transferring real estate. And I was explaining that we will have a rental value of these properties and this can have a financial impact on cash flow. So, we need to make the rules very conscious so as not to hinder the operation. They are very important in regulating corporate governance.
\end{abstract}

According to E5, "the budget is a fundamental part so that we do not spend more than we can. So, I see budget as a backbone". The matriarch E7, who acts as financial director and in the follow-up of the stores, states that:

Yes, what I want most, what we are fighting, that within the budget, implemented according to the view of the company, the way it is growing, in a format to give continuity, this way. In a way that it can keep up, move on and grow right?

Still on the E4 budget, he says: "I think that the budget can guarantee the continuity of the organization's processes, maintaining the level of improvement of the areas, and still guiding the new direction, so to speak, regarding profitability." E4 also emphasizes that the budget will serve as a guideline "so that the company does not lose its purpose ... it will not be lost".

In addition, trusted employees cited by the matriarch as potential candidates for leadership transfer emphasize the need for budget as a form of control, security, and organization (E3, E4). In this sense, E4 stresses that assuming leadership

\begin{abstract}
it would make it easier to manage the areas and ensure that they run the resources more efficiently... Providing more transparency to the board members as to what decisions to make. The budget would be a conduit for decisions and improvements. It would give more security for decision-making. It would have a north with respect to values.
\end{abstract}

Thus, Table 4 shows the stages of the succession process and contributions to the implementation of the budget. It presents in summary form aspects inherent to the planning stages of the process of succession based on Le Breton-Miller et al. (2004), involving the basic rules and the first steps, the training of the family and non-family successors that act in the management, and transference of leadership and property which consequently require the budget and contribute to its implementation based on Hansen and Van Der Stede (2004). 


\section{Table 4}

Stages of the succession process and contributions to budget implementation

It began in 2010 with the illness of the patriarch.

Suspended in 2011 after the death of the patriarch due to disagreements between the heirs.

Resumed in 2018 with the intention of the matriarch to leave the management (E7). Firstborn showed no desire to leave the business, but the lack of interest of his heirs in acting in the management (E5, E7).

Lack of interest of the youngest heir and his successors to continue acting in the management after the departure of the matriarch (E6, E7).

Hiring of consultancy to support the process.

Vision for the firm's future: remain family-owned with continued growth (E5, E6, E7). Profile of potential successor: willing to give continuity to the business, being able to be one of the members of the administrative committee that has a significant time working in the company and that was formed by the founders. Knower of leadership style and the values of family and business. With interest in growing and continuing in the company making the business continue to grow (E7).

Establishment of rules

Participants of the succession task force

Positions that will have succession

Who will make the choices

Criteria of choice

Possibilities of resources

Evaluation procedures

Potential candidates

Establishment of steps and deadlines

Choice of the potential successor

Holdings created, for example, leasing of real estate

Governance

Family committee

Follow-up of the successor's development and performance
Reasons for using the budget:

Operational planning

Strategic training

Future evaluation of performance

Antecedents of the reasons for using the budget

Organizational structure: matrix, branches, distribution center, and carrier (organizational units)

Organizational strategies: emphasis on cost leadership from loss control (E5) and quality of purchases (E6)

Succession planning strategies: creation of the family holding company (E4); hiring of trained external managers for specific areas (E7) or analysis of potential non-family successor among members of the administrative committee (E7); implementation of family governance (E4, E5)

Operational environment: traceability of resources allocated to products and services (E6)

External environment: high competition and focused on products and services (E5) Succession process: business vision; goals; implementation of strategies; coordination and control of activities; financial impacts (cash flow)

\section{Heirs}

Training at work: during the development of the business; heirs have been in business since childhood

Formal education: the firstborn graduated in agronomy and the youngest in marketing and advertising

$\stackrel{\infty}{=}$ Experience outside the company: firstborn worked in a multinational of agricultural products and actively participates in the Brazilian Association of Supermarkets Updating and training courses: offered by the company including to the heirs and also done on their own initiative with the support of the company

Potential non-family successors

Members of the administrative committee

Training at work: the three oldest were formed and trained by the founders

Formal education: all have higher education in specific courses of their work area

or graduate degrees in the area of activity

Experience outside the company: everyone has experience in other companies

External members

There was no successful selection

After the death of the patriarch, there was no transfer of leadership in the Retail

Group, which remained with the matriarch

The young heir took over the leadership of the horticultural sector, an activity he already worked with the patriarch

Departure of an heir from the management

There was a transfer of ownership in relation to the capital of the deceased patriarch Hiring of consultants to support resuming the succession process

Transfer of capital of the matriarch Continuity of growth (opening of new branches, expansion of regional coverage) Financial impacts: cash flow

Different scenarios

Control, organization, monitoring, security

Source: Elaborated by the authors. 
The reasons for the use of the budget arise in different and opposite circumstances, being linked to the antecedents of these reasons (Hansen \& Van Der Stede, 2004). The antecedents of these reasons characterize their necessity and in the Retail Group they are due to succession, part of the organizational life cycle, whose reflection is related to formalization of the controls and professionalization of the management. These aspects are inherent to the organizational structure, organizational strategy, operational environment, and external environment arising from the future vision of the business that is to remain family-owned with continued growth (E5, E6, E7).

The need for the budget in the family business in process of succession, object of study, is conceived according to the operational planning and the strategic formation, which is justified by the antecedents of the reasons for the budget, which arose under different circumstances (Hansen \& Van der Stede, 2004) related to the succession process.

\section{FINAL CONSIDERATIONS}

This study aimed to understand how the budget need is conceive in a family business in a process of succession, moment of the organizational life cycle. In this sense, a case study was carried out in a family-owned company located in the state of Paraná, which operates in the supermarket retail segment.

The results showed that Retail Group, after 50 years of existence, is at the growth stage when considering its history and expansion policy, as well as the process of succession. There was the intergenerational succession of the patriarch, who passed away in 2011. The succession of the matriarch and the heirs themselves is something that worries them and that raised the need to re-plan the succession, hiring a non-family manager, from family governance.

During the life cycle of Retail Group, the search for formalization started with the internalization of accounting in 1995, and in the course of time, especially since 2010, which generally included the implementation of an ERP system, restructuring the organization chart, hiring of controller, financial, human resources, external auditing, and, more recently, logistics consultants. Taking into consideration the specific company and among the possible aspects, the budget need is conceived according to the succession of the deceased patriarch, the policy of expansion of branches, and succession of the matriarch and heirs, circumstances that characterize the antecedents of the reasons for using the budget, resulting in the need for the tool.

The succession process backed up by its stages implies aspects that are reflected in the vision of the business and goals (Le Breton-Miller et al., 2004) that require budget support as a form of control and support in making shortor long-term decisions in this context (Hansen \& Van der Stede, 2004). In this sense, the contribution of this study lies in the consideration of intergenerational succession (Sharma, Chrisman, \& Chua, 2003) as a driver of budget implementation, since the reasons for the budget arise in different circumstances (Hansen \& Van der Stede, 2004) and, in this study, related to succession.

As a limitation of this study, the interviewees' selfreport on their perception of reality and subjectivity in the transcription and analysis of the data is considered, considering the adoption of the qualitative content analysis, which starts from the interpretation of the researchers about the interviewee's perception regarding the issue studied. Thus, it is suggested to deepen the study with a new data collection considering the followup of the implementation of the budget, as well as the planning of succession of matriarch and heirs considering succession strategies. As a suggestion of future research, it is recommended to consider the companies in which succession is planned and occurring, and that the budget is outlined in organizational routines.

\section{REFERENCES}

Anthony, R. N., \& Govindarajan, V. (2008). Sistemas de controle gerencial. São Paulo, SP: McGraw-Hill.

Associação Paranaense de Supermercados. (2017). Saiba mais sobre os serviços oferecidos pela APRAS. Retrieved from http://www.apras.org.br/.
Assunção, R. R., Luca, M. M. M., Vasconcelos, A. C., \& Cardoso, V. I. C. (2014). Os artefatos da contabilidade gerencial e o ciclo de vida organizacional. ConTexto, 14(28), 68-82.

Bauer, M. W., Gaskell, G. (2017). Pesquisa qualitativa com texto, imagem e som: um manual prático (13a. ed.). Petrópolis, RJ: Vozes. 
Bracci, E., \& Maran, L. (2012). The role and use of management accouting systems (MAS) in family firms: A case study. Piccola Impresa/Small Business, 3(2012).

Bruns, W. J., \& Waterhouse, J. H. (1975). Budgetary control and organization structure. Journal of Accounting Research, 13(2), 177-203.

Cabrera-Suárez, K., De Saá-Pérez, P., \& García-Almeida, D. (2001). The succession process from a resource-and knowledge-based view of the family firm. Family Business Review, 14(1), 37-48.

Cançado, V. L., Lima, J. B., Muylder, C. F., \& Castanheira, R. B. (2013). Ciclo de vida, sucessão e processo de governança em uma empresa familiar: um estudo de caso no Grupo Seculus. REAd-Revista Eletrônica de Administração, 19(2), 485-516.

Cesaroni, F. M., \& Sentuti, A. (2019). Il cambiamento dei sistemi di controllo manageriale e il processo di successione nelle imprese familiari. Quali possibili relazioni? Management Control, 1(1), 17-44.

Child, J. (1997). Strategic choice in the analysis of action, structure, organizations and environment: Retrospect and prospect. Organization Studies, 18(1), 43-76.

Chrisman, J. J., Chua, J. H., Sharma, P., \& Yoder, T. R. (2009). Guiding family businesses through the succession process. The CPA Journal, 79(6), 48.

Chua, J. H., Chrisman, J. J., \& Sharma, P. (1999). Defining the family business by behavior. Entrepreneurship Theory and Practice, 23(4), 19-39.

Daspit, J. J., Holt, D. T., Chrisman, J. J., \& Long, R. G. (2015). Examining family firm succession from a social exchange perspective: A multiphase, multistakeholder review. Family Business Review, 29(1), 44-64.

De Massis, A., \& Kotlar, J. (2014). The case study method in family business research: Guidelines for qualitative scholarship. Journal of Family Business Strategy, 5(1), 15-29.

Ferreira, A., \& Otley, D. (2009). The design and use of performance management systems: An extended framework for analysis. Management Accounting Research, 20(4), 263-282.

Flores, J. E., Jr., \& Grisci, C. L. I. (2012). Dilemas de pais e filhos no processo sucessório de empresas familiares. Revista de Administração, 47(2), 325-337.

Frezatti, F., Bido, D. D. S., Mucci, D. M., \& Beck, F. (2017). Estágios do ciclo de vida e perfil de empresas familiares brasileiras. RAE-Revista de Administração de Empresas, 57(6), 601-619.

Frezatti, F., Relvas, T. R. S., Nascimento, A. R., Junqueira, E. R., \& Bido, D. S. (2010). Perfil de planejamento e ciclo de vida organizacional nas empresas brasileiras. Revista de Administração, 45(4), 383-399.

Gersick, K. E., Davis, J. A., Hampton, M. M., \& Lansberg, I. (1997). De geração para geração: ciclos de vida da empresa familiar. São Paulo, SP: Negócio.

Giovannoni, E., Maraghini, M. P., \& Riccaboni, A. (2011). Transmitting knowledge across generations: The role of management accounting practices. Family Business Review, 24(2), 126-150.
Handler, W. C. (1994). Succession in family business: A review of the research. Family Business Review, 7(2), 133-157.

Hansen, S. C., \& Van der Stede, W. A. (2004). Multiple facets of budgeting: An exploratory analysis. Management Accounting Research, 15(4), 415-439.

Le Breton-Miller, I., Miller, D., \& Steier, L. P. (2004). Toward an integrative model of effective FOB succession. Entrepreneurship Theory and Practice, 28(4), 305-328.

Leotta, A., Rizza, C., \& Ruggeri, D. (2017). Management accounting and leadership construction in family firms. Qualitative Research in Accounting \& Management, 14(2), 189-207.

Lester, D. L., Parnell, J. A., \& Carraher, S. (2003). Organizational life cycle: A five-stage empirical scale. The International Journal of Organizational Analysis, 11(4), 339-354.

Lester, D. L., Parnell, J. A., \& Menefee, M. L. (2009). Organizational life cycle and innovation among entrepreneurial enterprises. Journal of Small Business Strategy, 19(2), 37-50.

Lodi, J. B. (1998). A empresa familiar (5a. ed.). São Paulo, SP: Pioneira.

Malmi, T., \& Brown, D. A. (2008). Management control systems as a package-Opportunities, challenges and research directions. Management Accounting Research, 19(4), 287-300.

Mamede, G., \& Mamede, E. C. (2011). Holding familiar e suas vantagens: planejamento jurídico e econômico do patrimônio e da sucessão familiar. Rio de Janeiro, RJ: Atlas.

Marques, L., da Cunha, P. R., Baldo de Faveri, D., \& Mayara Walter, F. (2014). Relação entre o ciclo de vida organizacional e o processo orçamentário em empresas metal mecânicas do alto e médio Vale do Itajaí. Enfoque: Reflexão Contábil, 33(2), 1-18.

Merchant, K. A., \& Van der Stede, W. A. (2007). Management control systems: Performance measurement, evaluation and incentives. Harlow: Pearson Education.

Miller, D., \& Friesen, P. H. (1983). Successful and unsuccessful phases of the corporate life cycle. Organization Studies, 4(4), 339-356.

Miller, D., \& Friesen, P. H. (1984). A longitudinal study of the corporate life cycle. Management Science, 30(10), 1161-1183.

Moores, K., \& Mula, J. (2000). The salience of market, bureaucratic, and clan controls in the management of family firm transitions: Some tentative Australian evidence. Family Business Review, 13(2), 91-106.

Moraes, R. (2003). Uma tempestade de luz: a compreensão possibilitada pela análise textual discursiva. Ciência \& Educação, 9(2), 191-211.

Nordqvist, M., Wennberg, K., \& Hellerstedt, K. (2013). An entrepreneurial process perspective on succession in family firms. Small Business Economics, 40(4), 1087-1122.

Nunes, R., Filho. (2018). O crescimento está de volta. SuperHiper, 44(501). Retrieved from http://www.abras.com.br/edicoesanteriores/Main.php?MagID=7\&MagNo=235.

Oliveira, J. L. de, Albuquerque, A. L., Pereira, R. D. (2012). Governança, sucessão e profissionalização em uma empresa 
familiar: (re)arranjando o lugar da família multigeracional. Revista Brasileira de Gestão de Negócios, 14(43), 176-192.

Oliveira, L. G. M., \& Silva, G. A. V. da (2012). Sucessão em uma empresa familiar: valores, racionalidades e dilemas. Revista de Administração FACES Journal, 11(2), 28-42.

Oro, I. M., \& Lavarda, C. E. F. (2019). Interface dos sistemas de controle gerencial com a estratégia e medidas de desempenho em empresa familiar. Revista Contabilidade Finanças, 30(79), 14-27.

Petry, L. I., \& Nascimento, A. M. (2009). Um estudo sobre o modelo de gestão e o processo sucessório em empresas familiares. Revista Contabilidade \& Finanças, 20(49), 109-125.

Quinn, R. E., \& Cameron, K. (1983). Organizational life cycles and shifting criteria of effectiveness: Some preliminary evidence. Management Science, 29(1), 33-51.

Roth, L., Tissot, M. C. H., \& Gonçalves, R. B. (2017). Family owned business succession and governance: A multiple case study in Brazil. Revista de Ciências da Administração, 19(48), 96-107.
Salvato, C., \& Moores, K. (2010). Research on accounting in family firms: Past accomplishments and future challenges. Family Business Review, 23(3),193-215.

Sampieri, R. H., Collado, C. F., \& Lucio, M. P. B. (2013). Metodologia de pesquisa (5a. ed.). Porto Alegre, RS: Penso.

Sharma, P., Chrisman, J. J., \& Chua, J. H. (2003). Succession planning as planned behavior: Some empirical results. Family Business Review, 16(1), 1-15.

Silva, A. da, Jr., \& Muniz, R. M. (2006). Sucessão, poder e confiança: um estudo de caso em uma empresa familiar capixaba. RAUSP Management Journal, 41(1), 107-117.

Stake, R. (2011). Pesquisa qualitativa: estudando como as coisas funcionam. Porto Alegre, RS: Penso.

Vancil, R. F. (1973). What kind of management control do you need? Harvard Business Review, 51(2), 75-86.

Waiandt, C., \& Davel, E. (2008). Organizações, representações e sincretismo: a experiência de uma empresa familiar que enfrenta mudanças e sucessões de gestão. Revista de Administração Contemporânea, 12(2), 369-394. 